\title{
ASSESSMENT KEBUTUHAN PEDOMAN PENYUSUNAN PROGRAM BIMBINGAN DAN KONSELING KOMPREHENSIF PADA GURU BIMBINGAN DAN KONSELING TINGKAT SMK DI KOTA YOGYAKARTA
}

\author{
Nindiya Eka Safitri ${ }^{(1)}$, Dwi Putranti ${ }^{(2)}$ \\ Program Studi Bimbingan dan Konseling \\ Fakultas Keguruan dan Ilmu Pendidikan \\ Universitas Ahmad Dahlan \\ E-mail: nindiya1315001306@,webmail.uad.ac.id
}

\begin{abstract}
Abstrak
Program bimbingan dan konseling komprehensif disusun berdasarkan kebutuhan peserta didik dan lingkungannya. Sekolah Menengah Kejuruan (SMK) menyiapkan lulusan yang siap kerja sehingga memerlukan program bimbingan dan konseling komprehensif yang menunjang tujuan pendidikan di SMK. Penelitian ini bertujuan untuk mengetahui kebutuhan guru bimbingan dan konseling akan pedoman penyusunan program bimbingan dan konseling komprehensif di tingkat SMK. Metode penelitian yang digunakan dalam penelitian ini adalah penelitian kulitatif menggunakan instrumen berupa wawancara dan studi dokumentasi dengan teknik analisis model Miles dan Hubbersman. Hasil penelitian menunjukkan bahwa guru bimbingan dan konseling di SMK cenderung menginginkan pedoman penyusunan program bimbingan dan konseling komprehensif dalam bentuk cetak. Adapun kajian materi yang dibutuhkan meliputi pengembangan rasional, visi dan misi, deskripsi kebutuhan, tujuan layanan, komponen layanan, bidang layanan, pengembangan tema/topik, evaluasi, pelaporan dan tindak lanjut, anggaran biaya dan rencana kegiatan (action plans).
\end{abstract}

Kata Kunci: guru BK, bimbingan dan konseling, komprehensif, SMK

\begin{abstract}
Comprehensive guidance and counseling program based on the needs of students and the environment. Vocational School prepare work-ready graduates,soneeds acomprehensive guidance and counseling programs that support the purpose of vocational education. The aim of this study was to know guidance and counseling teacher needs to be guidelines for the preparation of a comprehensive guidance and counseling program at the vocational level. Methode that used in this research is qualitative research using instruments such as interviews and documentation study with the model analysis techniques Miles and Hubbersman. The results showed that guidance and counseling teachers in vocational tend to want a guide guidance and counseling program comprehension in printed model. The material that required includes the rational development, vision and mission, a description of the need, the purpose of service, service parts, field service, development of themes/topics, evaluation, reporting and follow-up, budget and action plans.
\end{abstract}

Key words: teacher, guidance and counseling, comprehensive, vocational school

\section{Info Artikel}

Diterima April 2017, disetujui Mei 2017, diterbitkan Juni 2017 


\section{PENDAHULUAN}

Pendidikan pada dasarnya adalah upaya pengembangan potensi peserta didik. Dalam Undang-Undang Nomor 20 Tahun 2003 tentang Sistem Pendidikan Nasional diamanatkan bahwa pendidikan nasional bertujuan untuk mengembangkan potensi peserta didik agar menjadi manusia yang beriman dan bertakwa kepada Tuhan Yang Maha Esa, berakhlak mulia, sehat, berilmu, cakap, kreatif, mandiri dan menjadi warga negara yang demokratis serta bertanggung jawab. Selain itu, pendidikan juga memiliki fungsi pengembangan. Fungsi pengembangan yang dimaksud adalah membantu individu mengembangkan diri secara tepat sesuai dengan fitrah (potensi) dan keragaman (differensial) sehingga dapat berkembang menjadi pribadi yang utuh.

Dalam rangka membantu pengembangan potensi peserta didiktidak cukup hanya dilakukan melalui kegiatan belajar-mengajar. Bimbingan dan konseling sebagai bagian integral proses pendidikan memiliki kontribusi dalam pengembangan potensi peserta didik. Dalam perspektif bimbingan dan konseling, peserta didik merupakan individu sedang berada dalam proses berkembang atau menjadi (becoming), yaitu berkembang ke arah kematangan atau kemandirian. Untuk mencapai kematangan, individu memerlukan bimbingan, karena masih kurang memahami kemampuan dirinya, lingkungannya dan pengalaman untuk mencapai kehidupan yang bermutu. Oleh karena itu, diperlukan layanan bimbingan dan konseling yang tidak hanya memandang masalah dari sudut pandang peserta didik tetapi juga memperhatikan faktor-faktor dari lingkungan sekitar peserta didik (Caraka \& Nindiya, 2015: 55).

Saat ini telah terjadi perubahan paradigma pendekatan bimbingan dan konseling, yaitu dari pendekatan yang berorientasi tradisional, remedial, klinis, dan terpusat pada konselor kepada pendekatan yang berorientasi perkembangan dan preventif. Sebagaimana pendapat Sutoyo, dkk (2015: 48) bahwa BK perkembangan berbicara "fokus" atau pusat perhatian membantu perkembangan potensi, sedangkan BK komprehensif bicara "cakupan aspek" yang dikembangkan yang menyeluruh (komprehensif), artinya bukan hanya aspek jasmani saja, atau rohani saja, tetapi menyeluruh". Orientasi dari BK perkembangan adalah terwujudnya perkembangan yang optimal pada diri siswa. Sitti \& Caraka (2016: 270) menyatakan bahwa "optimum development is not limited to the achievement of achievement in accordance with the intellectual capacity and interest, but as a developmental condition that allow leaners are able to make choice and decisions in responsibility and adaptability to the dynamics of their life." 
Model bimbingan dan konseling berorientasi perkembangan dan preventif disebut juga dengan bimbingan dan konseling komprehensif. Model program bimbingan dan konseling komprehensif mulai berkembang di beberapa negara maju di Amerika Serikat semenjak tahun 1970-an. Oleh karena itu, program bimbingan dan konseling yang disusun di sekolahhendaknya merupakan program yang realistik, implementatif, sesuai kebutuhan peserta didik dan sinkron dengan program lainnya serta mendapat dukungan dari seluruh stakeholder pendidikan. Hal ini senada dengan pernyataan Juntika (2011: 13), bahwa untuk mencapai standar kemampuan profesional, akademik dan perkembangan peserta didik yang optimal diperlukan pendidikan dengan model bimbingan komprehensif yang bermutu.

Adapun model bimbingan komprehensif sendiri menurut Gysbers dan Henderson (2012: 62) adalah " $A$ comprehensive guidance and counseling program is a program as having a common language organizational framework with a spesific configuration of planned, sequenced, and coordinated guidance and counseling activities and services based on student, school, and community needs and resources, designed to serve all students and their parents or guardians in a local school district". Secara ringkas, bimbingan dan konseling komprehensif adalah sebuah program yang memiliki organisasi dengan perencanaan, pembagian dan pengkoordinasian khusus untuk aktivitas bimbingan dan konseling berdasarkan kebutuhan siswa, sekolah dan masyarakat. Program ini dirancang untuk melayani seluruh siswa dan orang tua atau pihak-pihak yang ada di sekolah. Dengan demikian, program ini dilakukan secara menyeluruh dari aspek komponen layanan dan sasaran layanan.

Model bimbingan dan konseling komprehensif didasarkan pada prinsip bimbingan dan konseling perkembangan. Dimana program disusun berdasarkan karakteristik dan kebutuhan peserta didik pada berbagai tingkat dan tahapan perkembangan. Dengan kata lain, bimbingan dan konseling komprehensif adalah program yang harus mampu menetapkan tujuan-tujuan, memprediksi hasil, menentukan strategi layanan, dukungan sistem serta kebijakan yang tepat, baik bagi siswa, guru $\mathrm{BK} /$ konselor, guru mata pelajaran, wali kelas, orang tua, maupun masyarakat. Dengan demikian, program ini berfungsi sebagai sarana pengembangan potensi siswa dalam bidang pribadi, sosial, belajar dan karir yang melibatkan sejumlah stakeholder sekolah.

Kaitannya dengan bimbingan dan konseling komprehensif, pemerintah Indonesia telah mengeluarkan Peraturan Menteri 
Pendidikan Nasional Nomor 27 Tahun 2008 tentang Standar Kualifikasi Akademik dan Kompetensi Konselor. Dalam permendiknas ini dijelaskan bahwa guru $\mathrm{BK} /$ konselor dituntut untuk dapat merancang dan mengimplementasikan program bimbingan dan konseling yang komprehensif. Tuntutan ini sebagaimana dijelaskan pada butir D nomor 13 yang meliputi, (a) menganalisis kebutuhan konseli, (b) menyusun program bimbingan dan konseling berkelanjutan berdasarkan kebutuhan peserta didik secara komprehensif dengan pendekatan perkembangan, (c) menyusun rencana pelaksanaan program bimbingan dan konseling; serta (d) merencanakan sarana dan biaya penyelenggaraan program bimbingan dan konseling.

Hal tersebut sesuai dengan standar yang ditentukan oleh Council for Accreditation of Counseling and Related Educational Program (CACREP) tahun 2009 dalam Dollarhide (2012: 3) bahwa konselor sekolah harus mampu merancang, mengimplementasikan dan mengevaluasi program bimbingan dan konseling komprehensif; merancang kegiatan untuk memfasilitasi peserta didik mengembangkan kompetensi akademik, karir dan pribadi-sosial; serta mengetahui dasar hukum dan kode etik dalam praktek konseling di sekolah.

Berdasarkan uraian di atas, dapat diidentifikasi bahwa dalam perancangan program bimbingan dan konseling komprehensif tidak hanya sebatas menyusun saja. Melainkan dimulai dari proses panjang dan mencakup bagian yang cukup banyak. Guru BK/konselor di sekolah perlu memahami langkah-langkah atau prosedur penyusunan program bimbingan dan konseling komprehensif. Penyusunan program bimbingan dan konseling komprehensif umumnya diawali dengan melakukan analisis kebutuhan konseli baru kemudian dilakukan penyusunan struktur program.

Untuk dapat mengadopsi program bimbingan dan konseling komprehensif, pemerintah Indonesia kembali mengeluarkan Permendikbud Nomor 111 Tahun 2014 tentang Bimbingan dan Konseling Pada Pendidikan Dasar dan Pendidikan Menengah. Permendikbud ini memberikan pedoman bagi penyelenggaraan layanan bimbingan dan konseling di pendidikan dasar dan menengah dengan menggunakan program bimbingan dan konseling komprehensif. Permendikbud ini tidak secara eksplisit membahas tentang bimbingan dan konseling komprehensif. Akan tetapi, substansi dari permendikbud ini menjelaskan model bimbingan dan konseling komprehensif. Dengan diberlakukannya permendikbud ini, mengamanatkan bahwa dalam implementasi layanan bimbingan dan konseling di Indonesia harus mengacu pada program bimbingan dan konseling komprehensif. 
Bagi guru BK/konselor di sekolah, pemberlakuan permendikbud ini berdampak signifikan pada administrasi dan prosedur pelayanan bimbingan dan konseling. Dalam konteks pelayanan bimbingan dan konseling terjadi perubahan paradigma baru, termasuk dalam penyusunan program bimbingan dan konseling berbasis komprehensif. Guru $\mathrm{BK} /$ konselor dituntut untuk memahami secara lebih mendalam tentang konsep dasar teoritis dan praksis bimbingan dan konseling komprehensif termasuk cara penyusunan program bimbingan dan konseling komprehensif sesuai dengan tugas perkembangan peserta didik pada jenjang sekolah tertentu.

Untuk jenjang Sekolah

Menengah Kejuruan (SMK), penyusunan program bimbingan dan konseling komprehensif memiliki karakteristik tersendiri. Sekolah Menengah Kejuruan (SMK) merupakan satuan pendidikan formal yang menyelenggarakan pendidikan kejuruan pada jenjang pendidikan menengah (UU Sisdiknas No. 20/2003). Sebagaimana dijelaskan dalam Permendikbud Nomor 70 Tahun 2013 tentang Kerangka Dasar dan Struktur Kurikulum SMK/MAK, bahwa peserta didik di tingkat SMK dididik agar siap untuk langsung bekerja di dunia kerja. Pendidikan di SMK difokuskan pada pengembangan minat dan potensi diri melalui berbagai program keahlian yang ditawarkan di sekolah menengah kejuruan. Dengan demikian, penyusunan program bimbingan dan konseling komprehensif di SMK lebih mengarah pada penyiapan lulusan yang siap siap kerja. Dalam hal ini, guru BK di SMK harus mampu memahami dan merancang program bimbingan dan konseling komprehensif di SMK yang dapat memfasilitasi pengembanganpotensi peserta didik untuk persiapan memasuki dunia kerja.

Faktanya, sebagian guru $\mathrm{BK} /$ konselor di tingkat SMK belum memahami secara utuh konsep dasar dan cara penyusunan program bimbingan konseling komprehensif. Hasil penelitian Kumara (2015) tentang program bimbingan dan konseling komprehensif pada tingkat SMK dalam Jurnal Konseling Komprehensif mengungkapkan bahwa sebagian besar guru BK SMK di Kabupaten Bantul memiliki pemahaman tentang manajemen program BK komprehensif dalam kategori sedang (60,5\%). Sedangkan guru yang termasuk dalam kategori tinggi sebanyak 4 orang guru (10,5\%), sangat tinggi $(5,4 \%)$, dan rendah $(23,6 \%)$. Kesimpulannya adalah bahwa guru BK SMK di Kabupaten Bantul memiliki pemahaman terhadap manajemen program BK komprehensif dalam kategori sedang.

Penelitian Hesty Nurrahmi (2015) tentang kompetensi guru BK tingkat SMK di Pontianak dalam merancang program juga menunjukkan bahwa guru BK tingkat 
SMK dalam merancang program berada pada kategori kurang menguasai $(52,63 \%)$. Masih ditemui guru bimbingan dan konseling yang belum memiliki kemampuan optimal dalam menyelenggarakan program bimbingan dan konseling terutama dalam merancang dan menyusun program bimbingan dan konseling. Sementara itu, hasil penelitian terbaru oleh Juli Wantoro (2016) tentang profil tingkat pemahaman guru BK di SMK Negeri se-kota Yogyakarta dalam penyusunan program bimbingan dan konseling komprehensif menunjukan bahwa profil tingkat pemahaman guru BK di SMK Negeri se-kota Yogyakarta dalam penyusunan program BK komprehensif secara keseluruhan menunjukan kategori sedang, yaitu sebanyak 14 guru (50\%), jika dilihat dari masing-masing aspek. Profil tingkat pemahaman guru bimbingan dan konseling dalam penyusunan program BK komprehensif adalah aspek 1 berada pada kategori sedang yaitu sebanyak 14 guru (50\%), aspek 2 berada pada kategori sedang yaitu sebanyak 24 guru $(85,7 \%)$, aspek 3 berada pada kategori tinggi yaitu sebanyak 17 guru (60,7\%), aspek 4 berada pada kategori rendah yaitu sebanyak 17 guru $(60,7 \%)$ dan aspek 5 berada pada kategori sedang yaitu sebanyak 12 guru (42, 9\%).

Berdasarkan beberapa hasil penelitian di atas, diketahui bahwa kemampuan guru $\mathrm{BK} /$ konselor di SMK dalam menyusun program bimbingan dan konseling komprehensif belum maksimal. Perlu adanya usaha untuk meningkatkan kemampuan guru BK tingkat SMK dalam menyusun program bimbingan dan konseling komprehensif. Oleh karena itu, penulis tertarik untuk melakukan survei atau studi tentang kebutuhan guru BK akan pedoman penyusunan program bimbingan dan konseling komprehensif, khususnya untuk tingkat Sekolah Menengah Kejuruan (SMK).

\section{METODE PENELITIAN}

Metode penelitian yang digunakan dalam penelitian ini adalah penelitian kulitatif (qualitatif research) yakni penelitian yang menghasilkan penemuan yang tidak dicapai dengan menggunakan prosedur statistik atau cara lain dari kualifikasi (pengukuran). Moleong (2002: 9) mendefinisikan penelitian kualitatif sebagai penelitian yang menghasilkan data deskriptif berupa kata-kata tertulis atau lisan dari orangorang dan perilaku yang dapat diamati. Lebih lanjut, Sugiyono (2013: 1) mengatakan bahwa penelitian kualitatif adalah penelitian yang digunakan untuk meneliti kondisi objek yang alamiah, dimana peneliti adalah instrumen kunci, analisis data yang bersifat induktif, dan hasil penelitiannya lebih menekankan makna daripada generalisasi.

Adapun subyek penelitian yang digunakan dalam penelitian ini adalah guru bimbingan dan konseling di 
SMK Negeri se-Kota Yogyakarta yang telah lulus sertifikasi. Subjek yang memenuhi kriteria ini ada sejumlah 25 orang guru. Penelitian ini dilakukan selama kurang lebih 4 bulan, dimulai pada bulan Januari sampai dengan April 2017. Adapun tempat penelitian meliputi 7 (tujuh) SMK Negeri di Wilayah Kota Yogyakarta. Selanjutnya, penelitian ini menggunakan teknik pengumpulan data yang bersifat non tes, yaitu wawancara, observasi, dan studi dokumentasi.

Adapun teknik analisis data yang digunakan dalam penelitian ini adalah dengan mengacu pada konsep model Miles dan Huberman (dalam Sugiyono, 2013: 91-99) yaitu interactive model yang mengklasifikasikan analisis data dalam tiga langkah, meliputi data collection, data reduction, data display dan counclusions drawing/verifying. Berikut ini adalah gambar yang menerangkan tentang langkah analisis data kualitatif menggunakan model Miles and Hubbersman.

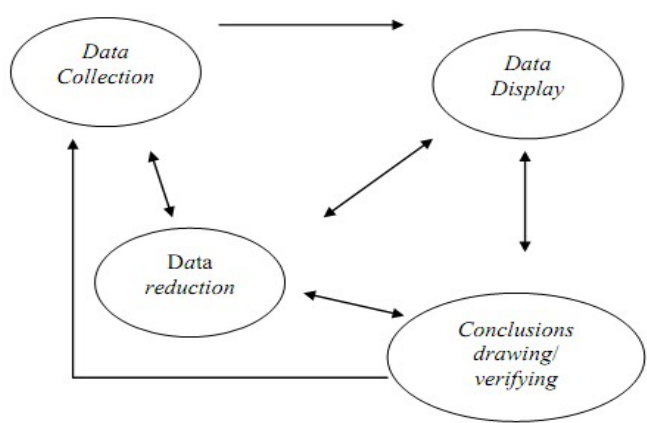

Gambar 1. Model Miles adn Hubbersman

\section{HASIL PENELITIAN \\ DAN} PEMBAHASAN

Berdasarkan hasil kegiatan wawancaradengan sejumlah guru di sekolah SMK Negeri di wilayah Kota Yogyakarta, diperoleh keterangan bahwa sejumlah guru BK masih kurang memahami tentang penyusunan program BK komprehensif sehingga memerlukan pedoman atau panduan tentang penyusunan program bimbingan dan konseling komprehensif. Sebagian besar guru BK mengaku bahwa dirinya paham tentang program bimbingan dan konseling komprehensif tetapi masih dalam konsep teoritis. Untuk tataran praktis, guru BK mengakui bahwa belum dapat melakukannya secara maksimal.

Selain itu, sejumlah guru BK juga memberikan keterangan bahwa kegiatan pelatihan dan diklat tentang penyusunan program bimbingan dan konseling di tingkat SMK telah dilakukan oleh berbagai pihak. Akan tetapi, pada umumnya kegiatan pelatihan hanya berisikan materi secara teoritis, belum menyinggung tataran praksis secara mendetail. Guru BK menerangkan pula bahwa belum terdapat panduan tertulis yang baku tentang penyusunan program bimbingan dan konseling. Mereka hanya diberikan contoh dalam bentuk softfile.

Berdasarkan hasil observasi dan studi dokumentasi, juga diperoleh keterangan bahwa format program bimbingan dan konseling yang 
disusun oleh guru BK belum seragam. Dalam satu sekolah, terdapat perbedaan cara menyusun program bahkan komponen program yang ada di dalamnya juga berbeda. Peneliti juga memperoleh keterangan bahwa tidak semua guru BK paham dan menggunakan Permendikbud Nomor 111 Tahun 2014 sebagai acuan penyusunan program. Berdasarkan hasil studi dokumentasi, juga ditemukan bahwa format administrasi BK di sejumlah sekolah masih belum ada kesamaan dan kesesuaian dengan format yang sebenarnya.

Dalam hal ini, peneliti melakukan analisis tentang ketertarikan dan kebutuhan guru BK di SMK akan pedoman penyusunan program BK komprehensif dalam bentuk cetak. Hasil analisis mengungkapkan guru BK bahwa membutuhkan media cetak berupa bacaan yang disertai dengan contohcontoh agar dapat menyusun program bimbingan dan konseling. Dari sini diperoleh hasil data bahwa guru BK lebih menginginkan adanya pedoman tertulis tentang penyusunan program bimbingan dan konseling komprehensif. Di antara berbagai bentuk pedoman yang ditawarkan, guru BK lebih memilih modul ataupun buku panduan. Guru BK juga menyampaikan bahwa di wilayah kota Yogyakarta belum terdapat modul terkait hal ini, sehingga berharap bahwa adanya sebuah modul tentang penyusunan program yang dapat membantu guru BK. Mereka menginginkan bahwa dalam modul diberikan uraian langkah-langkah operasional dalam menyusun program bimbingan dan konseling di SMK. Selain itu, di dalamnya juga disertai contoh-contoh konkrit dan relevan serta mudah dipamahi oleh guru BK. Contoh yang dimaksud adalah contohcontoh dan draft (isian/form/borang) struktur program BK komprehensif untuk tingkat SMK.

Untuk dapat meningkatan kemampuan guru BK dalam menyusun program bimbingan dan konseling komprehensif di Sekolah Menengah Kejuruan (SMK), memang diperlukan media inovatif yang mampu memberikan pedoman bagi guru BK di SMK, khususnya SMK Negeri di wilayah kota Yogyakarta. Sebagaimana diungkapkan oleh Sukmadinata (2013: 165) bahwa untuk dapat meningkatkan kemampuan guru yang tersebar dalam suatu daerah yang sangat luas membutuhkan bahan latihan atau penataran yang disusun dalam bentuk modul. Selain itu, media modul juga menjadi rekomendasi dari hasil penelitian Juli Wantoro (2016) bahwa pengembangan modul program BK komprehensif untuk guru bimbingan dan konseling merupakan alternatif pilihan yang tepat bagi peneliti yang akan datang sebagai tindak lanjut hasil penelitian ini. Dengan alasan karena hal itu sangat berguna untuk guru bimbingan dan konseling supaya dapat meningkatkan pemahaman dalam penyusunan program bimbingan dan konseling 
komprehensif melalui modul program BK komprehensif. Di samping itu, modul program BK komprehensif selama ini di lapangan masih sangat jarang yang mengembangkan.

Adapun modul sendiri merupakan salah satu bentuk bahan ajar yang dikemas secara utuh dan sistematis, di dalamnya memuat seperangkat pengalaman belajar yang terencana dan didesain untuk membantu peserta didik menguasai tujuan belajar yang khusus. Modul juga dapat diartikan sebagai materi pelajaran yang disusun dan disajikan secara tertulis sedemikian rupa sehingga pembacanya diharapkan dapat menyerap sendiri materi tersebut. Dengan kata lain, modul adalah sebagai bahan belajar dimana pembacanya dapat belajar mandiri (Daryanto, 2013: 9).

Tujuan pembuatan atau penyusunan modul menurut Prastowo (2012: 108) antara lain adalah: a) agar peserta didik dapat belajar secara mandiri tanpa atau dengan bimbingan pendidik (yang minimal), b) Agar peran pendidik tidak terlalu dominan atau otoriter dalam kegiatan pembelajaran, c) Melatih kejujuran peserta didik, d) Mengakomodasi berbagai tingkah dan kecepatan belajar serta peserta didik, dan e) Agar peserta didik mampu mengukur sendiri tingkat penguasaan materi yang telah dipelajari. Tujuan dari pembuatan modul ini untuk memberikan pemahaman dan ketrampilan sehingga guru BK SMK dapat memiliki pemahaman akan materi tentang penyusunan program bimbingan dan konseling komprehensif. Harapannya, modul tersebut dapat dikembangkan secara terarah dan sistematis sehingga dapat menjadi bahan belajar bagi peserta didik yang dalam hal ini adalah guru BK di SMK. Sedangkan tujuan pembelajaran dalam modul pada dasarnya adalah untuk meningkatkan pemahaman dan kemampuan guru BK di SMK dalam menyusun program bimbingan dan konseling komprehensif secara mandiri, serta secara baik dan benar.

Selanjutnya adalah hasil penelitian kaitannya dengan materi penyusunan program bimbingan dan konseling komprehensif yang dibutuhkan oleh guru BK di SMK. Berdasarkan analisis wawancara, diperoleh keterangan bahwa guru BK memiliki pemahaman yang kurang dan memerlukan sejumlah penjelasan tertulis tentang beberapa struktur program bimbingan dan konseling komprehensif. Keterangan yang diberikan oleh guru BK sejalan dengan substansi dalam Permendikbud Nomor 111 Tahun 2014. Oleh karena itu, peneliti juga melakukan telaah teoritis terhadap substansi Permendikbud No. 111 Tahun 2014 tentang Bimbingan dan Konseling Pada Pendidikan Dasar dan Menengah. Dimana di dalam lampiran permendikbud ini, guru BK dituntut untuk dapat menyusun program bimbingan dan konseling 
komprehensif yang terdiri dari 10 (sepuluh) struktur program, yaitu rasional, visi dan misi, deskripsi kebutuhan, tujuan layanan, komponen layanan, bidang layanan, pengembangan tema/topik, evaluasi, pelaporan dan tindak lanjut, anggaran biaya dan rencana kegiatan (action plans).

\section{SIMPULAN}

DAN

\section{REKOMENDASI}

Pemahaman guru BK di sekolah-sekolah SMK di Kota Yogyakarta tentang penyusunan program bimbingan dan konseling komprehensif masih kurang. Pemahaman secara teoritis telah dimiliki oleh sebagain kecil guru BK. Akan tetapi, pemahaman secara praksis belum banyak dipahami, khusunya tentang penyusunan program bimbingan dan konseling yang sesuai dengan struktur program bimbingan dan konseling komprehensif yang sebenarnya.

Secara umum, telah banyak dilakukan diklat atau pelatihan atau workshop yang memberikan pemahaman tentang program bimbingan dan konseling komprehensif. Akan tetapi, para guru BK tidak diberikan contoh eksplisit tentang cara penyusunannya. Sebagian besar guru BK menginginkan contohcontoh penyusunan program bimbingan dan konseling komprehensif dalam bentuk tulisan (cetak). Dari beberapa media cetak yang ditawarkan, guru BK memilih media dalam bentuk modul. Mereka menginginkan bahwa dalam modul diberikan uraian langkah-langkah operasional dalam menyusun program bimbingan dan konseling di SMK. Selain itu, di dalamnya juga disertai contoh-contoh konkrit dan relevan serta mudah dipamahi oleh guru BK.

Oleh karena itu, peneliti memberikan rekomendasi kepada penelitian selanjutnya tentang urgensi pengembangan modul tentang penyusunan program bimbingan dan konseling komprehensif di sekolah. Modul hendaknya disusun dan didesain sedemikian rupa sehingga dapat memberikan pemahaman bagi guru BK. Modul hendaknya mudah dibaca dan mudah digunakan oleh guru BK secara fleksibel dalam berbagai tahapan penyusunan program bimbingan dan konseling di sekolah. Adapun substansi modul yang direkomendasikan hendaknya fokus tentang komponen program layanan bimbingan dan konseling komprehensif. Dalam modul ini dibahas 10 (sepuluh) aspek atau bagian dalam program bimbingan dan konseling komprehensif, lengkap dengan uraian materi, contoh dan evaluasi (latihan mandiri). Modul ini akan menjawab kebutuhan guru bimbingan dan konseling akan pedoman penyusunan program bimbingan dan konseling secara baik dan tepat. Dengan adanya modul ini, maka guru bimbingan dan konseling akan memperoleh tambahan pemahaman dan ketrampilan dalam 
hal menyusun program bimbingan dan konseling komprehensif.

\section{DAFTAR PUSTAKA}

Budhi Handaka, I., \& Eka Safitri, N. 2016, March. Pemanfaatan Metode Experiential Learning Untuk Meningkatkan Keterampilan Berpikir Kritis Siswa Dalam Belajar. In Prosiding Seminar Nasional "Optimalisasi Active Learning dan Character Building dalam Meningkatkan Daya Saing Bangsa di Era Masyarakat Ekonomi Asean (MEA)" (pp. 157-164). Prodi Pendidikan Guru Sekolah Dasar dan Prodi Bimbingan dan Konseling.

Caraka, P.B., \& Nindiya. E. S. 2015. Implementasi Permendikbud RI Nomor 111 Tahun 2014 Dalam Pengembangan Layanan BK di Sekolah Menengah. In Prosiding Seminar Nasional Bimbingan Dan Konseling (pp. 55-61).

Daryanto. 2013. Menyusun Modul: Bahan Ajar Untuk Persiapan Guru Dalam Mengajar. Yogyakarta. Gava Media.

Dollarhide. 2011. Comprehensive School Counseling Programs: K-12 Delivery Systems in Action (2nd Edition). Pearson.

Gysbers, N.C., \& Henderson P. 2012. Developing and Managing Your School Guidance and Counseling Program FIFTH Edition. Alexandria. American Counseling Assosiation.
Hasan, S.U.N., \& Bhakti. C. P. 2016. Guidance and Counselling: A Comparison between Indonesia and Malaysia. Scientific Journal of PPI-UKM, 3(6), 267-271.

Hidayat, Dede Rahmat. 2013. Bimbingan Konseling: Kesehatan Mental Di sekolah. Bandung. Remaja Rosda Karya.

Juliwantoro. 2016. Profil Tingkat Pemahaman Guru BK Dalam Menyusun Program BK Komprehensif SMK Negeri seKota Yogyakarta. Jurnal Skripsi Bimbingan dan Konseling UAD. September 2016.

Juntika. 2011. Membangun Peradaban Bangsa Indonesia Melalui Pendidikan dan Komprehensif Bermutu. Disampaikan dalam pidato Pengukuhan Prof. Dr. H. Juntika, M.Pd sebagai Guru Besar/Profesor dalam Bidang Bimbingan dan Konseling Pada Fakultas Ilmu Pendidikan Universitas Pendidikan Indonesia.

Agus, R. Kumara. 2015. Pemahaman Guru Bimbingan dan Konseling Terhadap Program Bimbingan dan Konseling Komprehensif Di SMK Negeri se-Kabupaten Bantul. Jurnal Konseling Komprehensif. Vol.2, No. 1, ISSN: 2355-7303, hal. 12-18. 
Moleong, Lexy. 2002. Metode Penelitian Kualitatif. Bandung: PT Remaja Rosdakarya.

Nurrahmi, Hesty. 2015. Kompetensi Profesional Guru Bimbingan dan Konseling. Jurnal Dakwah Alhikmah. Vol. 9, No.1. Pontianak: IAIN Pontianak.

Peraturan Menteri Pendidikan dan Kebudayaan Nomor 111 Tahun 2014 tentang Bimbingan dan Konseling Pada Pendidikan Dasar dan Menengah.

Peraturan Menteri Pendidikan Nasional Nomor 27 Tahun 2008 tentang Standar Kualifikasi Akademik dan Kompetensi Konselor.

Peraturan Menteri Pendidikan Nasional Nomor 70 Tahun 2013 tentang Kerangka Dasar dan Struktur Kurikulum Sekolah Mengah Kejuruan/Madrasah Aliyah Kejuruan.
Prastowo, Andi. 2012. Panduan Kreatif Membuat Bahan Ajar Inovatif. Jogjakarta. Diva Press.

Sugiyono. 2016. Metode Penelitian Pendidikan: Pendekatan Kuantitatif, Kualitatif, dan $R \& D$. Bandung. Alfabeta.

Sukmadinata, Nana Syaodih. 2013. Metode Penelitian Pendidikan. Bandung. PT Remaja Rosdakarya.

Sutoyo, Anwar dkk. (2015). Bimbingan dan Konseling Perkembangan. Semarang: Pasca Sarjana Bimbingan dan Konseling UNNES.

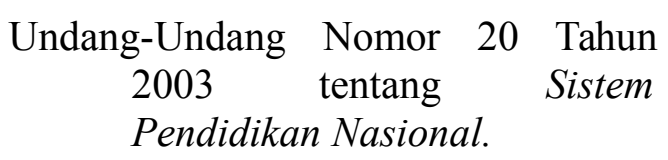

